\title{
Insulin Receptor Biosynthesis in Cultured Lymphocytes from Insulin-resistant Patients
}

\author{
Jose A. Hedo, Victoria Y. Moncada, and Simeon I. Taylor \\ Diabetes Branch, National Institute of Arthritis, Diabetes, Digestive and Kidney Diseases, \\ National Institutes of Health, Bethesda, Maryland 20892
}

\begin{abstract}
In some patients with genetic forms of extreme insulin resistance, the cause of insulin resistance is a marked $(\geqq 90 \%)$ reduction in the number of insulin receptors on the cell surface. In the present work, we describe studies of insulin receptor biosynthesis in Epstein-Barr virus (EBV)-transformed lymphocytes from three patients (A-1, A-5, and A-8) with type $A$ extreme insulin resistance.

Insulin receptors are composed of two major glycoprotein subunits (apparent molecular weight $\left[M_{\mathrm{r}}\right]$ of 135 and $95 \mathrm{kD}$ ), which are both derived from a common precursor molecule with $M_{\mathrm{r}}$ of $190 \mathrm{kD}$. In one patient (A-1), there was a marked reduction in the biosynthesis of both the $190-\mathrm{kD}$ precursor and the mature receptor. Thus, in this pationt, the defect appears to occur early in the biosynthetic pathway (i.e., before the synthesis of the 190$k D$ precursor). In contrast, in two sisters (A-5 and A-8) with type A extreme insulin resistance, biosynthesis of the 190-kD precursor proceeds at a normal rate. However, there appears to be a defect subsequent to the biosynthesis of the $190-\mathrm{kD}$ precursor, but before the insertion of the mature receptor in the plasma membrane. Our observations suggest the existence of at least two distinct types of biosynthetic defects which may give rise to a marked reduction in the number of insulin receptors on the cell surface.

In addition, for comparison, we have studied receptor biosynthesis in cultured EBV lymphocytes from a fourth patient (A-7) with type A extreme insulin resistance. Although the cells of patient A-7 have a normal number of insulin receptors, we have detected subtle abnormalities in the posttranslational processing of the insulin receptor precursor, which may be a biochemical marker for a postbinding defect that causes insulin resistance in this patient.
\end{abstract}

\section{Introduction}

Cell surface receptors play a central role in mediating many important physiological processes, including hormone action and receptor-mediated endocytosis $(1,2)$. Defects in these cell surface receptors contribute importantly to the pathogenesis of many human diseases (1-5). In fact, in several rare genetic disease states, the primary defect appears to be a marked reduction in the number of receptors at the cell surface (3-7). The genetic syndromes of extreme insulin resistance are among the best studied of these diseases $(3,4,8-10)$.

Address correspondence to Dr. Taylor, National Institutes of Health, Building 10, Room 8N250, Bethesda, MD 20892.

Received for publication 23 May 1985.

The Journal of Clinical Investigation, Inc

Volume 76, December 1985, 2355-2361
Recently, we have reported that cultured lymphocytes transformed with Epstein-Barr virus (EBV) ${ }^{1}$ provide a powerful tool for investigating genetic diseases affecting the insulin receptor $(4,8,10-15)$. In the present work, we have studied the biosynthesis of insulin receptors in cultured lymphocytes from four patients with the syndrome of type A extreme insulin resistance. As compared with normal subjects, three of these patients have a marked reduction $(\geqq 90 \%)$ in the number of insulin receptors at the cell surface. In one patient (A-1), the reduction in receptor number results from a defect in receptor biosynthesis. In two other patients (A-5 and A-8), the receptor precursor is synthesized at a normal rate but there appears to be a block before the insertion of the mature receptor in the plasma membrane. In contrast, cells from the fourth patient (A-7) possess a normal number of insulin receptors. However, receptors from patient A-7 fail to couple insulin binding to insulin action, possibly as a result of a defect in the receptor-associated protein kinase (16). Interestingly, there appeared to be subtle defects in the posttranslational processing of insulin receptors from cells of patient A-7.

\section{Methods}

Patients. We have studied four patients with the syndrome of type A extreme insulin resistance (Table I). All studies were approved by the Institutional Review Board of the National Institute of Arthritis, Diabetes, Digestive and Kidney Disease. Informed consent was obtained in all cases.

Cells. Lymphocytes were obtained from heparinized peripheral blood samples and transformed in vitro with EBV, according to previously established methods $(8,12)$. Cells were grown in RPMI-1640 medium supplemented with $10 \%$ fetal calf serum (8). ${ }^{125}$ I-Insulin binding studies were carried out as described elsewhere $(8,12) .{ }^{125} \mathrm{I}$-Insulin binding is presented as the ratio of bound to free ${ }^{125} \mathrm{I}$-insulin (B/F) at a cell density of $10^{7}$ cells $/ \mathrm{ml}$ and an ${ }^{125} \mathrm{I}$-insulin concentration of $0.1 \mathrm{ng} / \mathrm{ml}$.

Pulse-chase labeling studies (method I). In some experiments (Figs. 1 and 2), cells were pulse-labeled according to minor modifications of the method of Hedo et al. (21). In all experiments, a paired experimental design was employed in which two cell lines (one from a normal subject and one from an insulin-resistant patient) were studied on the same day under identical conditions. Stationary phase cells $\left(\sim 2 \times 10^{9}\right.$ cells $)$ were sedimented by centrifugation, washed, and resuspended at a density of $\sim 10^{7}$ cells $/ \mathrm{ml}$ in glucose-free RPMI-1640 medium supplemented with Hepes $(25 \mathrm{mM}$ ) plus $10 \%$ dialyzed fetal bovine serum. After incubation at $37^{\circ} \mathrm{C}$ for $30 \mathrm{~min}$, the cells were sedimented by centrifugation and resuspended at a density of $\sim 4 \times 10^{7}$ cells $/ \mathrm{ml}$ in fresh glucose-free medium containing $\sim 0.75 \mathrm{mCi} / \mathrm{ml}$ of $\left[2{ }^{3} \mathrm{H}\right]$ mannose, and then, incubated at $37^{\circ} \mathrm{C}$ for $45 \mathrm{~min}$. At this point, the cells were sedimented by centrifugation, resuspended at a density of $2 \times 10^{6} \mathrm{cells} / \mathrm{ml}$ in complete RPMI1640 supplemented with $10 \%$ fetal bovine serum plus unlabeled mannose $(2 \mathrm{mM})$, and incubated at $37^{\circ} \mathrm{C}$ for $0-6 \mathrm{~h}$.

1. Abbreviations used in this paper: $\mathrm{B} / \mathrm{F}$, ratio of bound to free ${ }^{125} \mathrm{I}-$ insulin; EBV, Epstein-Barr virus; SDS-PAGE, sodium dodecyl sulfatepolyacrylamide gel electrophoresis. 
Table I. Characteristics of Patients

\begin{tabular}{|c|c|c|c|c|c|}
\hline \multirow[b]{2}{*}{ Patient } & \multirow[b]{2}{*}{$\begin{array}{l}\text { Fasting } \\
\text { plasma } \\
\text { glucose }\end{array}$} & \multirow[b]{2}{*}{$\begin{array}{l}\text { Fasting } \\
\text { plasma } \\
\text { insulin }\end{array}$} & \multicolumn{2}{|c|}{$\begin{array}{l}{ }^{125} \mathrm{I} \text {-insulin bound } \\
\left(\% / 10^{7} \text { cells per } \mathrm{ml}\right)\end{array}$} & \multirow[b]{2}{*}{ References } \\
\hline & & & $\begin{array}{l}\text { Cultured EBV } \\
\text { lymphocytes }\end{array}$ & $\begin{array}{l}\text { Circulating } \\
\text { monocytes }\end{array}$ & \\
\hline
\end{tabular}

Type A insulin-resistant patients

$\begin{array}{llrrrr}\text { A-1 } & 200 & 125 & 2 & 0.5 & 8,9 \\ \text { A-5* } & 210 & 330 & 2 & 0.7 & 18,19 \\ \text { A-8* } & 315 & 110 & 4 & 0.6 & 18,19 \\ \text { A-7 } & 111 & 45 & 33 & 6.4 & 17\end{array}$

Normal volunteers

\begin{tabular}{cccccc} 
A.R. & 87 & - & 49 & - & 15 \\
P.L. & 82 & 6 & 62 & - & 15 \\
Y.G. & - & - & 32 & - & 15 \\
Normal range & $<10.5$ & $<20$ & $12-65$ & $4-11$ & \\
\hline
\end{tabular}

* Patients A-5 and A-8 are sisters who are both the product of a consanguineous marriage between two cousins.

Pulse-chase labeling (method II). Cultured lymphocytes $\left(\sim 2 \times 10^{9}\right.$ cells) were preincubated at $37^{\circ} \mathrm{C}$ for $45 \mathrm{~min}$ in $100 \mathrm{ml}$ of glucose-free RPMI-1640 supplemented with $10 \%$ dialyzed fetal calf serum. The cells were sedimented by centrifugation, resuspended in $100 \mathrm{ml}$ of glucosefree medium containing $\left[2-{ }^{3} \mathrm{H}\right]$ mannose $(0.25 \mathrm{mCi} / \mathrm{ml})$, and divided equally between two tissue culture flasks $\left(75 \mathrm{~cm}^{2}\right.$ surface area). After the cells were incubated with $\left[2-^{3} \mathrm{H}\right]$ mannose at $37^{\circ} \mathrm{C}$ for $60 \mathrm{~min}$, we added $1 \mathrm{ml}$ of "stop" solution containing mannose $(100 \mathrm{mM})$ and glucose $(500$ $\mathrm{mM}$ ) dissolved in complete RPMI-1640 medium containing $10 \%$ fetal calf serum to each flask. Thereafter, the incubation was extended for an additional 1.5 or $4 \mathrm{~h}$ of "chase." At each time point, one flask of cells was utilized. The cells were washed three times with phosphate-buffered saline and the cell pellet was frozen at $-20^{\circ} \mathrm{C}$ overnight. The following day, each cell pellet was solubilized in $2.5 \mathrm{ml}$ of $\mathrm{NaCl}(150 \mathrm{mM}) / \mathrm{Hepes}$ $(50 \mathrm{mM}, \mathrm{pH} 7.6) /$ Triton X-100 (2\%, vol:vol) containing phenylmethylsulfonyl fluoride $(2 \mathrm{mM})$ and aprotinin (1 trypsin inhibitory unit/ml). The cell suspension was stirred for $60 \mathrm{~min}$ on ice. Insoluble material was removed by centrifugation $(45,000 \mathrm{rpm}$ in Sorvall Ti865.1 rotor [E. I. DuPont de Nemours \& Co., Inc., Small Instruments Div., Newton,
CT]; $\left.60 \mathrm{~min} ; 4^{\circ} \mathrm{C}\right)$. The supernatants were incubated with Pansorbin (Calbiochem-Behring Corp., San Diego, CA) (0.15 ml of $20 \%$ suspension of Pansorbin for each milliliter of supernatant) for $30 \mathrm{~min}$ on ice. The Pansorbin was removed by centrifugation $(45,000 \mathrm{rpm}$ for $15 \mathrm{~min}$ at $4^{\circ} \mathrm{C}$ ). Aliquots of the supernatant fluid $(1 \mathrm{ml})$ were incubated overnight at $4^{\circ} \mathrm{C}$ with either antireceptor antiserum B-2 (dilution, 1:200) or normal human serum (dilution, 1:200). Pansorbin $(0.2 \mathrm{ml})$ was added to precipitate immune complexes. The immunoprecipitates were analyzed by sodium dodecyl sulfate-polyacrylamide gel electrophoresis (SDS-PAGE) as described below.

Pulse-chase labeling with $\left.{ }^{35} S\right]$ methionine was carried out exactly as with $\left[2-{ }^{3} \mathrm{H}\right]$ mannose with the following exceptions: $(a)$ Methionine-free RPMI-1640 was substituted for glucose-free medium; (b) During the labeling period, cells were suspended in $40 \mathrm{ml}$ of medium containing $\left[{ }^{33} \mathrm{~S}\right]$ methionine $(62.5 \mu \mathrm{Ci} / \mathrm{ml}) ;(c)$ To each flask, we added $100 \mathrm{ml}$ of "stop" solution which consisted of complete RPMI- 1640 supplemented with methionine $(1 \mathrm{mM})$ plus fetal calf serum (10\%).

The pulse-chase studies using $\left[{ }^{35} \mathrm{~S}\right]$ methionine and $\left[2-{ }^{3} \mathrm{H}\right]$ mannose were always carried out in parallel on the same day using the same batch of cells.

Determination of incorporation of radiolabeled precursors into TCAprecipitable material. In the pulse-chase labeling studies, we applied 0.02 $\mathrm{ml}$ of Triton extract of the cells (before ultracentrifugation) to a $15-\mathrm{cm}^{2}$ piece of Whatman 1 filter paper (Whatman Laboratory Products, Inc., Clifton, NJ). The filter papers were washed for $3 \mathrm{~d}$ in $10 \%$ TCA with three changes of the wash. The filters were allowed to dry at room temperature, and then, they were placed into scintillation vials containing $0.6 \mathrm{ml}$ of Protosol (New England Nuclear; Boston, MA) and $20 \mathrm{ml}$ of Econofluor 2 (New England Nuclear). After incubating the vials overnight at $37^{\circ} \mathrm{C}$, the radioactivity was determined with a scintillation counter. In general, the radioactivity incorporated into TCA-precipitable material was similar to that of cells from normal subjects and cells from insulinresistant patients studied the same day.

Cell surface iodination. The cell surface proteins of cultured lymphocytes were labeled by lactoperoxidase-catalyzed radioiodination, as described elsewhere $(11,15)$. The receptors were solubilized and immunoprecipitated, as described for the pulse-chase studies (vide supra).

Analytical SDS-PAGE. The receptors were solubilized in Triton X100 and immunoprecipitated with antireceptor antiserum B-2, as described elsewhere $(15,21,22)$. The immunoprecipitates were analyzed using SDS-PAGE electrophoresis followed by fluorography, according to previously described methods $(15,21,22)$. The specific bands were excised from the gel (Fig. 1) and the radioactivity was quantitated directly by liquid scintillation counting (21). In Fig. 6, a scanning densitometer was employed to estimate the intensity of each band on the autoradiogram. It was shown that under these conditions, the amount of radioactivity in a band is proportional to the integrated area under the corresponding peak in the densitometric tracing.
NORMAL (P.L.)

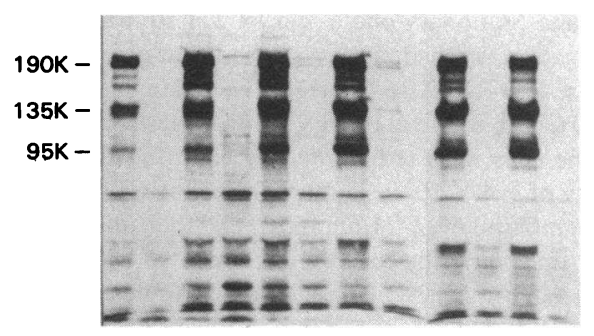

Anti-R

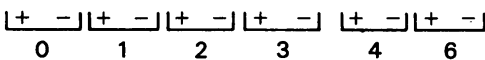

TYPE A (A-1)

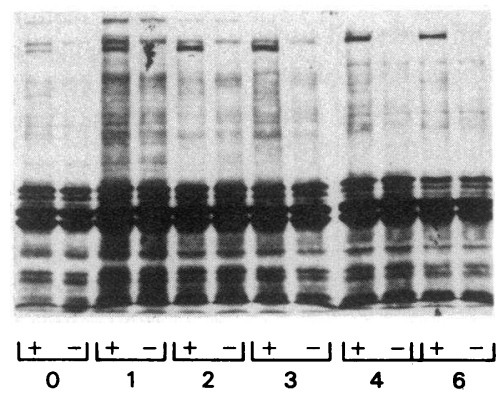

TIME OF CHASE (Hours)
Figure 1. Pulse-chase labeling of insulin receptors in cultured lymphocytes (normal subject vs. patient A-1). Cultured lymphocytes were incubated for $\mathbf{4 5}$ min with [2${ }^{3} \mathrm{H}$ ]mannose ("pulse") and then incubated with unlabeled mannose for $0-6 \mathrm{~h}$ ("chase") as described in method I (vide supra). The insulin receptors were solubilized in Triton X-100. Immunoprecipitation was carried out with either antireceptor antiserum (Anti-R) or normal human serum. The immunoprecipitates were analyzed by SDSPAGE. The figure is a fluorograph of the slab gel. The 135- and 95-kD bands are not well visualized on the photographic repro-

duction of the florograph of the gel from patient A-1. However, these bands may be demonstrated more clearly using other labeling methods such as cell surface radioiodination (15).

${ }^{125}$ I-insulin binding to the cultured cells was $B / F=1.60$ (normal subject P.L.) and $B / F=0.02$ (patient $A-1$ ). 


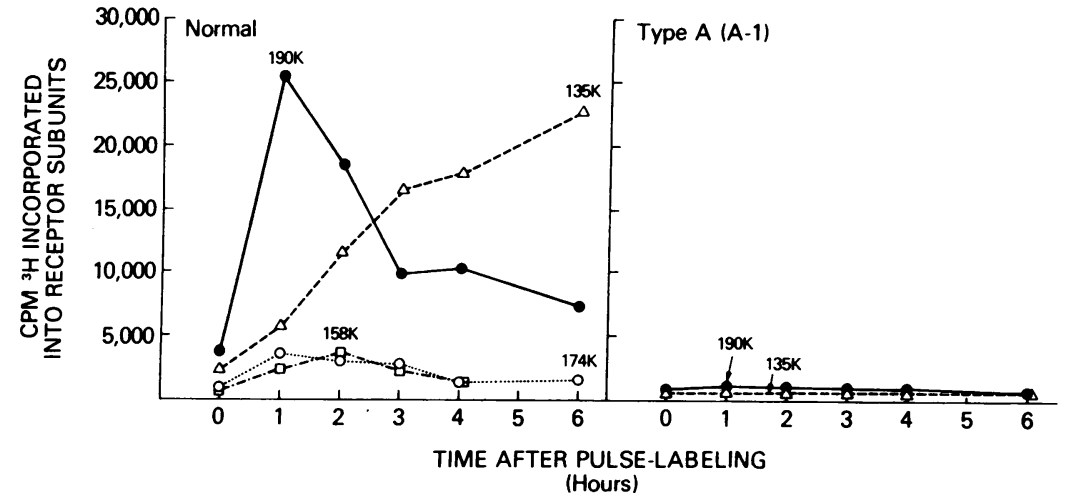

Figure 2. Time course of receptor biosynthesis in cells from a normal subject and patient A-1. Specifically immunoprecipitated bands were excised from the slab gel described in Fig. 1. The radioactivity in each band is plotted as a function of the time after pulse labeling: $190 \mathrm{kD},-\bullet-; 174 \mathrm{kD}, \cdots \circ \cdots ; 158 \mathrm{kD}, \cdots \bullet \cdots$ $135 \mathrm{kD},--\Delta--$.

\section{Results}

Cells from normal subjects. As shown previously in a number of cell types, insulin receptor biosynthesis proceeds via a precursor with an apparent molecular weight $\left(M_{\mathrm{r}}\right)$ of $190 \mathrm{kD}(21$, 23-25). This precursor, a single-chain glycoprotein with $N$-linked carbohydrate of the high mannose type, is processed to the mature receptor (135- and 95-kD subunits) by two steps: (a) peptide chain cleavage and $(b)$ maturation of the carbohydrate moiety to the complex type of $N$-linked carbohydrate. To demonstrate this pathway in the cultured lymphocytes, we have employed a pulse-labeling technique in which the cells were incubated for 45 min with [2- $\left.{ }^{3} \mathrm{H}\right]$ mannose ("pulse") followed by incubation for varying periods of time with unlabeled mannose ("chase"). With this protocol, incorporation of ${ }^{3} \mathrm{H}$ into the $190-\mathrm{kD}$ precursor was maximal at $1-2 \mathrm{~h}$ into the chase (Figs. 1 and 2 ). Consistent with a precursor-product relationship, incorporation of ${ }^{3} \mathrm{H}$ into the mature 135 - and $95-\mathrm{kD}$ subunits proceeded more slowly and continued to increase as late as $6 \mathrm{~h}$ into the chase period. Interestingly, in the EBV-transformed lymphocytes from normal subjects, there were also two minor bands with $M_{\mathrm{r}}$ of 174 and $158 \mathrm{kD}$. Although the 174- and 158-kD bands were only labeled $10-20 \%$ as intensely with $\left[2-{ }^{3} \mathrm{H}\right]$ mannose as the $190 \mathrm{kD}$ band, the labeling of all three bands followed similar kinetics (Figs. 1 and 2). The significance of the two minor bands (i.e., 158 and $174 \mathrm{kD}$ ) is not known 2 .

Cells from insulin-resistant patients with decreased receptor number. Previously, we have studied cultured lymphocytes from several insulin-resistant patients with a decrease in receptor number $(8,11,15,17)$. The receptor defects first observed in fresh cells have been preserved in the cultured lymphocytes despite transformation of the cells with EBV and growth in vitro $(8,10)$. In the present studies, we have investigated the biosynthesis of insulin receptors in three patients in whom extreme insulin resistance resulted from a marked reduction $(\geqq 90 \%)$ in the number of insulin receptors at the cell surface $(8,15)$.

Patient $A$-1. In pulse-labeling studies with cells from patient

2. Cloning of the complementary DNA for the insulin receptor has shown that the unglycosylated precursor of the insulin receptor has a predicted molecular weight of $152 \mathrm{kD}(25)$. Thus, it is possible that the 158- and $174-\mathrm{kD}$ forms are partially glycosylated forms en route to the $190-\mathrm{kD}$ precursor. However, one of us (J. A. Hedo, unpublished observations) has demonstrated that tryptic digestion of the $190-\mathrm{kD}$ precursor yields fragments with $M_{\mathrm{r}}$ 's of $\sim 160$ and $175 \mathrm{kD}$. Consequently, it is also possible that these minor bands represent partially degraded forms of the 190$\mathrm{kD}$ precursor.
A-1, there was a marked reduction in the rate of labeling of the $190-\mathrm{kD}$ precursor as well as the mature $135-$ and $95-\mathrm{kD}$ subunits of the insulin receptor. Based on ${ }^{125}$ I-insulin binding studies, we have estimated that the number of receptors on the surface of the cells from patient A-1 was reduced by $>95 \%$ as compared with the normal patient's cells (see legend to Fig. 1). There was a comparable reduction of the incorporation of ${ }^{3} \mathrm{H}$ into the 190 $\mathrm{kD}$ precursor (Figs. 1 and 2 ) in cells from patient $\mathrm{A}-1$. In these studies, we have utilized $\left[2-{ }^{3} \mathrm{H}\right]$ mannose to label the carbohydrate moiety of the insulin receptor. Clearly, the use of a labeled sugar has technical advantages over the use of a labeled amino acid in that the former approach minimizes the number of "nonspecific" radiolabeled bands visualized in the fluorograph of the gel (Fig. 3). However, if the defect in receptor biosynthesis interfered with glycosylation of the receptor, then our choice of $\left[2-{ }^{3} \mathrm{H}\right]$ mannose as the source of the label might have compromised our ability to detect an aglyco-form of the receptor. Therefore, we performed pulse-chase studies using $\left[{ }^{35} \mathrm{~S}\right]$ methionine to label the protein moiety of the receptor (Fig. 3 ). There was a comparable reduction of the rate of receptor biosynthesis irrespective of whether the receptor was labeled in its carbohydrate moiety with $\left[2-{ }^{3} \mathrm{H}\right]$ mannose or its protein moiety with $\left[{ }^{35} \mathrm{~S}\right]$ methionine (Fig. 3 ). To interpret these labeling studies, it is necessary to assume that the intracellular pools of methionine or mannose are labeled to the same specific activities in the two cell types. Two observations are reassuring in this regard: first, similar amounts of radioactivity are incorporated into TCA-precipitable material in both cell types (see Appendix $1)$, and second, studies with $\left[2-{ }^{3} \mathrm{H}\right]$ mannose and $\left[{ }^{35} \mathrm{~S}\right]$ methionine yield essentially identical conclusions.

Patients $A-5$ and $A-8$. These two patients are sisters who were the product of a marriage between first cousins (18). These two patients exhibit a reduction in the number of insulin receptors which is comparable with the decrease observed in patient A-1 (Table I). Nevertheless, a different biochemical mechanism appears to explain the defect observed in patients A-5 and A-8. Unlike our observations with cells from patient A-1 (Figs. 1-3), the rate of biosynthesis of the receptor precursor does not differ from normal in patient A-8 (Fig. 4). Similar results were obtained with cells from the sister, patient A-5 (data not shown). Therefore, it seems reasonable to conclude that there may be a block subsequent to the biosynthesis of the $190-\mathrm{kD}$ precursor, but before the insertion of the mature receptor subunits (i.e., 135 and 95 $\mathrm{kD}$ ) in the plasma membrane. In fact, there does appear to be a decrease in the radioactivity incorporated into the mature 135and $95-\mathrm{kD}$ receptor subunits in cells from patient A-8 (Fig. 4). However, because of the diffuse nature of these bands in pulse- 

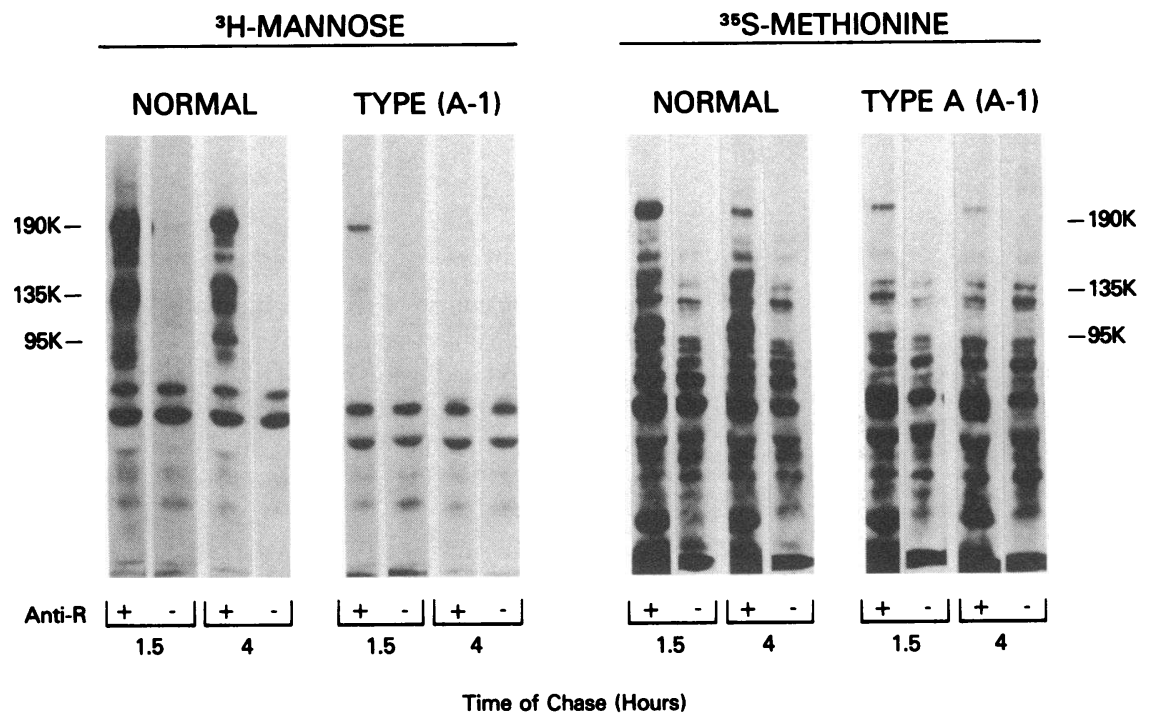

Figure 3. Pulse-chase labeling of insulin receptors (normal subject vs. patient A-1): comparison of $\left[2{ }^{3} \mathrm{H}\right]$ mannose and $\left[{ }^{35} \mathrm{~S}\right]$ methionine. Cultured lymphocytes from a normal subject (A.R.) and patient A-1 were incubated with [2$\left.{ }^{3} \mathrm{H}\right]$ mannose (left panel) or $\left[{ }^{35} \mathrm{~S}\right]$ methionine (right panel) for $1 \mathrm{~h}$. Thereafter, an excess of either unlabeled mannose or methionine was added and the incubation was extended for an additional 1.5 or $4 \mathrm{~h}$ as described in method II (vide supra). Immunoprecipitates were analyzed by SDS-PAGE as described in the legend to Fig. 1.

Incorporation of $\left[2-{ }^{3} \mathrm{H}\right]$ mannose and $\left[{ }^{35} \mathrm{~S}\right] \mathrm{methionine}$ into TCA-precipitable material was similar in the two cell lines, see Appendix 1.

chase labeling studies, it is difficult to obtain precise quantitation of the magnitude of the decrease.

Cells from an insulin-resistant patient $(A-7)$ with a normal number of insulin receptors. While insulin receptors of patient A-7 have been reported to have an impaired tyrosine-specific protein kinase activity on the basis of studies with circulating monocytes (17), this defect appears not to be expressed on the patient's EBV-transformed cultured lymphocytes $(17,20)$. Nevertheless, we have employed our methods to investigate the structure and biosynthesis of insulin receptors in this patient's cultured lymphocytes (Fig. 6). The 190-kD receptor precursor appears to be labeled normally with either $\left[2-{ }^{3} \mathrm{H}\right]$ mannose or $\left.{ }^{35} \mathrm{~S}\right]$ methionine at $1.5 \mathrm{~h}$ into the chase period (Fig. 5). However, the patient's insulin receptors exhibited at least one abnormality in these biosynthetic studies. Although the mobility of the 190$\mathrm{kD}$ receptor precursor does not appear to change during the chase period in cells from the normal subject, the precursor in

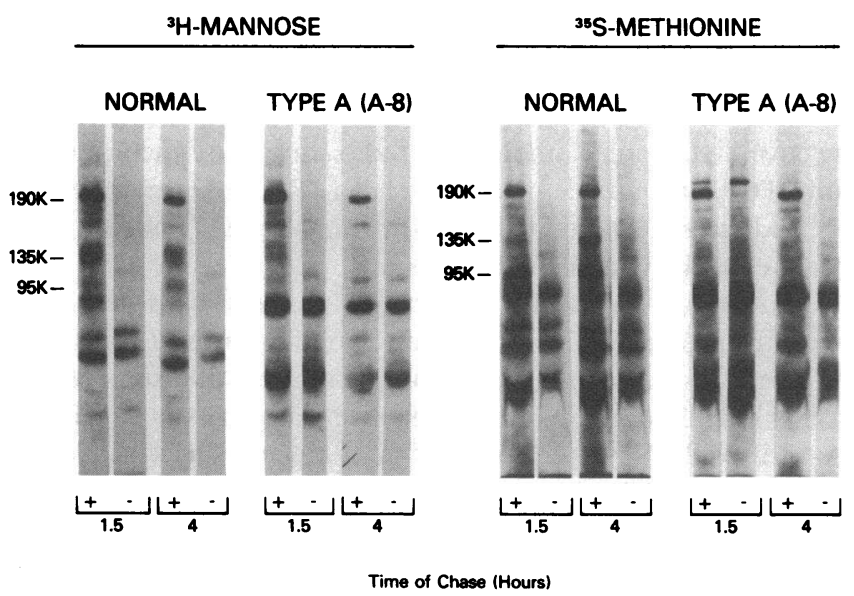

Figure 4. Pulse-chase labeling of insulin receptors in cultured cells from a normal subject and patient A-8. Insulin receptors on cultured lymphocytes from a normal subject and patient A-8 were labeled as described in the legend to Fig. 3.

Incorporation of $\left[2-{ }^{3} \mathrm{H}\right]$ mannose and $\left[{ }^{35} \mathrm{~S}\right]$ methionine into TCAprecipitable material was similar in the two cell lines, see Appendix 1.

Incorporation of $\left[2-{ }^{3} \mathrm{H}\right]$ mannose into the insulin receptor and its precursor was assayed by excising the bands followed by scintillation counting, see Appendix 2. cells from patient A-7 appears to be processed to a form with an $M_{\mathrm{r}}$ of $\sim 10-20 \mathrm{kD}$ higher than is observed in cells from the normal subject at $4 \mathrm{~h}$ in the chase period (Fig. 5).

To pursue this question, we labeled the subunits of the insulin receptor by lactoperoxidase-catalyzed radioiodination (Fig. 6). Using this technique, we did not detect any major abnormality in the $M_{\mathrm{r}}$ of the $\alpha$-subunit (135 kD) or $\beta$-subunit (95 kD). However, cells from patient A-7 did appear to possess a markedly increased number of uncleaved $210-\mathrm{kD}$ insulin receptor molecules (Fig. 6). Although comparable quantities of ${ }^{125}$ I were incorporated into the $135-\mathrm{kD}$ subunit in cells from patient A-7 and the normal subject, almost 10 -fold more radioactivity was incorporated into the $210-\mathrm{kD}$ band in cells from patient A-7 (see Appendix 3).

\section{Discussion}

In three of the patients whom we have studied, extreme insulin resistance can be explained by a marked reduction in the number of insulin receptors at the cell surface. Previously, we have studied the rate of receptor degradation in cultured cells from these patients (15). In those studies, the cell surface receptors were radioiodinated and the rate of receptor degradation was measured directly $(15,26,27)$. Because we did not observe a major increase in the rate of receptor degradation in cultured cells from the insulin-resistant patients, we concluded that the reduction in receptor number probably resulted primarily from defects in the biosynthetic pathway (15). In the present work, we have studied the rate of receptor biosynthesis directly. For all of our studies of receptor synthesis and degradation, we have employed cultured EBV-transformed lymphocyte cell lines derived from the patients. Indeed, for technical reasons, such studies are not presently feasible with any other cell type which is readily available from human patients. While one must be cautious about extrapolating from such in vitro studies to the situation in vivo, we have previously provided evidence that this cell type accurately reflects the situation in cells which have been obtained fresh from the patient $(3,4,8)$.

Molecular mechanisms. Interestingly, in the three patients with a decreased number of insulin receptors, we have obtained evidence for at least two different types of biochemical defects in the biosynthetic pathway for insulin receptors. In patient A1 , the biosynthetic defect must be before the synthesis of the 


\section{${ }^{3}$ H-MANNOSE}

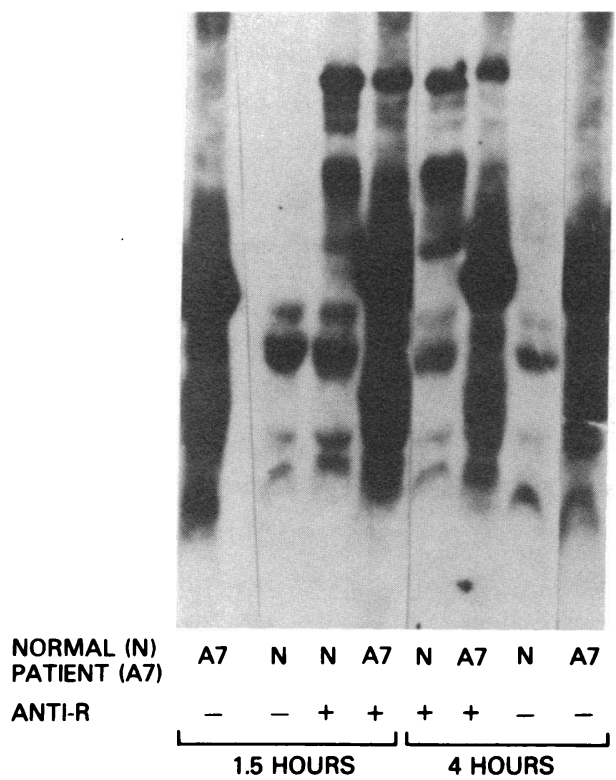

190-kD precursor. In contrast, with patients A-5 and A-8, the receptor precursor is synthesized at a normal rate. Moreover, as stated above, there is not a major abnormality in the rate of receptor degradation once the receptor had been inserted in the plasma membrane (15). Therefore, it seems likely that there must be a defect in receptor biosynthesis subsequent to the synthesis of the precursor, but prior to insertion of the mature receptor in the plasma membrane. However, our data do not allow us to define the precise nature of the defect. It is possible that there is a defect in the posttranslational processing of the receptor. Alternatively, there may be accelerated degradation of either the receptor or its precursors before insertion in the membrane. It is also possible that there may be a defect in the mechanism which anchors the receptor to the plasma membrane, as has been described in a mutant form of the low density lipoprotein receptor (7).

Although cells from patient A-7 have a normal number of insulin receptors, we have detected a subtle abnormality in the

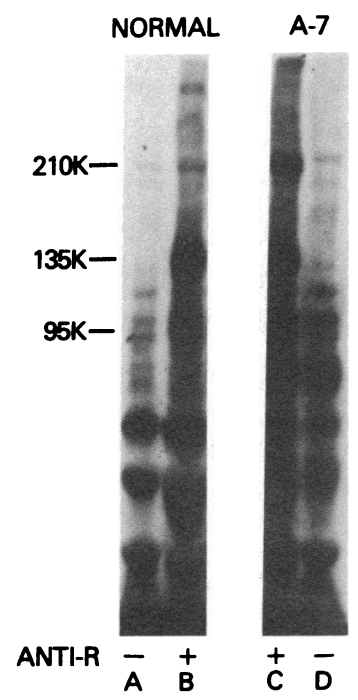

Figure 6. Cell surface iodination of insulin receptors in cultured cells from a normal subject and patient A-7. Cultured cells from normal subject Y.G. (lanes $a$ and $b$ ) or patient A-7 (lanes $c$ and $d$ ) were iodinated by lactoperoxidase-catalyzed radioiodination. Thereafter, receptors were solubilized, immunoprecipitated with normal serum (lanes $a$ and $d$ ) or antireceptor antiserum B-2 (lanes $b$ and $c$ ), and analyzed using SDS-PAGE.

The radioactivity (arbitrary units) in the 210- and 135-kD bands were estimated using scanning densitometry of the autoradiograph, see Appendix 3.
${ }^{35}$ S-METHIONINE

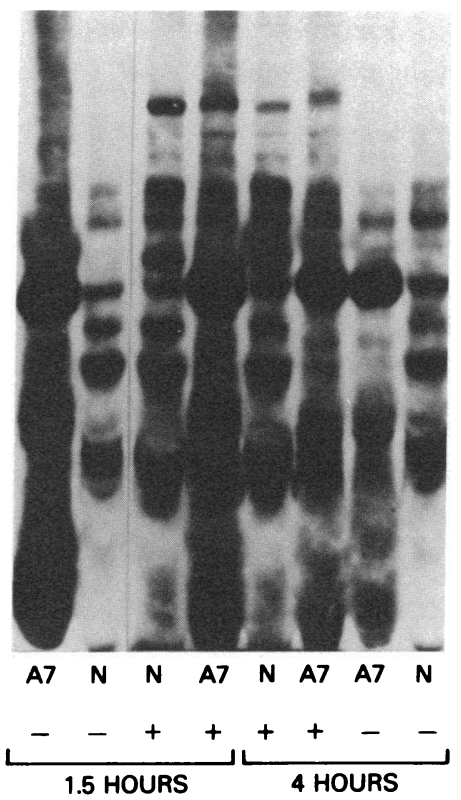

Figure 5. Pulse-chase labeling of insulin receptors in cultured cells from a normal subject and patient A-7. Insulin receptors on cultured lymphocytes from a normal subject (A.R.) and patient A-7 were labeled as described in the legend to Fig. 3.

Incorporation of $[2$ -

$\left.{ }^{3} \mathrm{H}\right]$ mannose and

$\left[{ }^{35} \mathrm{~S}\right]$ methionine into TCAprecipitable material was similar in the two cell lines, see Appendix 1.

posttranslational processing of the insulin receptor. Normally, the receptor precursor undergoes two processing steps to yield the mature receptor: endopeptidase cleavage, and the maturation of the carbohydrate moiety (Figs. 1 and 2). The 210-kD glycoprotein which is immunoprecipitated by antireceptor antibodies represents the small fraction of receptor molecules that have escaped endopeptidase cleavage but nevertheless have undergone maturation of the carbohydrate moiety and insertion into the plasma membrane (21). This $210-\mathrm{kD}$ species has previously been shown to function normally at least to the extent that it is capable of binding insulin and possesses insulin-stimulated protein kinase activity (28). Interestingly, in cells from patient A-7, the amount of the uncleaved 210-kD form of the receptor is increased almost 10-fold (Fig. 6). However, we do not yet understand either the explanation or the pathophysiological significance of this abnormality.

Diversity of biochemical defects. In previous studies, we and others have shown that there are multiple different types of receptor defects that may give rise to extreme insulin resistance $(3,4,8-17,29,30)$. Moreover, many patients with extreme insulin resistance do not possess any detectable defects in their insulin receptors $(3,4,31,32)$. In this work, we have shown that even patients such as A-1 and A-8 who appear to have similar clinical syndromes (i.e., type A extreme insulin resistance) and biochemical defects (i.e., a decrease in the number of insulin receptors) may have diverse molecular explanations for the reduction in receptor number. In fact, investigations of genetic diseases have generally shown that individual patients who have clinical phenotypes suggestive of "homozygosity" for defective genes may in reality be "genetic compounds"-i.e., patients who have inherited two different abnormal alleles at the same locus (5-7). Obviously, the possibility that patients may possess two distinct populations of receptors, each of which is abnormal in a different way, further complicates the interpretation of our studies. (Patients, such as A-5 and A-8, whose parents share genes in common because of consanguinity are more likely to be true homozygotes rather than genetic compounds.) Fortunately, as a result of the recent work by Ullrich et al. (25) to 
clone the complementary DNA which encodes the insulin receptor, it will soon be possible to determine directly whether these patients have mutations in the genes which encode their insulin receptors.

\section{Appendices}

Appendix 1: incorporation of labeled precursors into TCAprecipitable material. We assayed incorporation of $\left[{ }^{3} \mathrm{H}\right]$ mannose and $\left[{ }^{35} \mathrm{~S}\right]$ methionine into TCA-precitable material as described in Methods. In this table, we present data obtained in the three experiments described in Figs. 3-5.

\begin{tabular}{|c|c|c|c|c|}
\hline & \multicolumn{2}{|c|}{${ }^{3} \mathrm{H}$-incorporation } & \multicolumn{2}{|c|}{${ }^{35}$ S-incorporation } \\
\hline & $1.5 \mathrm{~h}$ & $4 \mathrm{~h}$ & $1.5 \mathrm{~h}$ & $4 \mathrm{~h}$ \\
\hline $\begin{array}{c}\text { Experiment } 1 \\
\text { (Fig. 3) }\end{array}$ & $\mathrm{cpm} / 0.0$ & & $c p m / 0.02 \mathrm{~m}$ & \\
\hline Normal & 413,000 & 199,000 & 514,000 & 429,000 \\
\hline Patient A-1 & 234,000 & 256,000 & 519,000 & 596,000 \\
\hline \multicolumn{5}{|l|}{$\begin{array}{c}\text { Experiment } 2 \\
\text { (Fig. 4) }\end{array}$} \\
\hline Normal & 113,000 & 151,000 & 540,000 & 497,000 \\
\hline Patient A-8 & 184,000 & 201,000 & 445,000 & 480,000 \\
\hline \multicolumn{5}{|l|}{$\begin{array}{c}\text { Experiment } 3 \\
\text { (Fig. 5) }\end{array}$} \\
\hline Normal & 361,000 & 356,000 & $2,340,000$ & $2,460,000$ \\
\hline Patient A-7 & 540,000 & 331,000 & $2,510,000$ & $1,720,000$ \\
\hline
\end{tabular}

Appendix 2: incorporation of $\left[2{ }^{3} \mathrm{H}\right]$ mannose into the insulin receptor and its precursor. In the experiment described in Fig. 4, we excised the regions of the gels corresponding to the bands with $M_{\mathrm{r}}$ of 190,135 , and $95 \mathrm{kD}$. The ${ }^{3} \mathrm{H}$-content of the gel slices was determined directly using a liquid scintillation counter.

\begin{tabular}{|c|c|c|c|c|c|c|}
\hline & \multicolumn{6}{|c|}{${ }^{3} \mathrm{H}$-incorporation (cpm) } \\
\hline & \multicolumn{2}{|l|}{$190 \mathrm{kD}$} & \multicolumn{2}{|c|}{$135 \mathrm{kD}$} & \multicolumn{2}{|l|}{$95 \mathrm{kD}$} \\
\hline & $1.5 \mathrm{~h}$ & $4 \mathrm{~h}$ & $1.5 \mathrm{~h}$ & $4 \mathrm{~h}$ & $1.5 \mathrm{~h}$ & $4 \mathrm{~h}$ \\
\hline Normal & 11,680 & 2,420 & 9,130 & 3,030 & 2,210 & 1,160 \\
\hline Patient A-8 & 7,920 & 2,150 & 2,550 & 1,090 & 263 & 280 \\
\hline
\end{tabular}

Appendix 3: ${ }^{125}$ I-content of receptor subunits in cells from patient $A-7$. In the experiment described in Fig. 6, a scanning densitometer was employed to estimate the radioactivity located in the regions of the gel corresponding to the bands with $M_{\mathrm{r}}$ of 210 and $135 \mathrm{kD}$.

\begin{tabular}{lccl}
\hline & \multicolumn{1}{l}{ 125 I-content (arbitrary units) } & \\
\cline { 2 - 4 } & $210 \mathrm{kD}$ & $135 \mathrm{kD}$ & $\begin{array}{l}\text { Ratio } \\
(210 \mathrm{kD} / 135 \mathrm{kD})\end{array}$ \\
\hline Normal & 9 & 250 & 0.036 \\
Patient A-7 & 73 & 288 & 0.253
\end{tabular}

\section{Acknowledgments}

We are grateful to Ms. Bernice Marcus-Samuels for assistance with growing the cells and performing insulin binding studies. Dr. Jesse Roth and Dr. Phillip Gorden provided support and encouragement throughout these studies. We also thank Dr. Richard Klausner and Dr. Aidan McElduff for helpful discussions. Mrs. Nancy Wigle provided expert secretarial assistance in preparing the manuscript.

This research was partially supported by the American Diabetes Association (Roger Staubach Research Feasibility Grant Award).

\section{References}

1. Roth, J., and S. I. Taylor. 1983. Information transfer, cell regulation and disease mechanisms: insights from studies of cell surface receptors. Harvey Lect. 22:81-128.

2. Brown, M. S., P. T. Kovanen, and J. L. Goldstein. 1981. Regulation of plasma cholesterol by lipoprotein receptors. Science (Wash. DC). 212: 628-635.

3. Grunberger, G., S. I. Taylor, R. F. Dons, and P. Gorden. 1983. Insulin receptor in normal and disease states. Clin. Endocrinol. Metab. 12:191-220.

4. Taylor, S. I. 1985. Receptor defects in patients with extreme insulin resistance. Diabetes/Metabolism Rev. 1:171-202.

5. Goldstein, J. L., and M. S. Brown. 1983. Familial hypercholesterolemia. In The Metabolic Basis of Inherited Disease. J. B. Stanbury, J. B. Wyngaarden, D. S. Fredrickson, J. L. Goldstein, and M. S. Brown, editors. McGraw-Hill, New York. 672-712.

6. Tolleshaug, H., K. K. Hobgood, M. S. Brown, and J. L. Goldstein. 1983. The LDL receptor locus in familial hypercholesterolemia: multiple mutations disrupt transport and processing of a membrane receptor. Cell. 32:941-951.

7. Lehrman, M. A., W. J. Schneider, T. C. Sudhof, M. S. Brown, J. L. Goldstein, and D. W. Russell. 1985. Mutation in LDL receptor: Alu-Alu recombination deletes exons encoding transmembrane and cytoplasmic domains. Science (Wash. DC). 227:140-146.

8. Taylor, S. I., B. Samuels, J. Roth, M. Kasuga, J. A. Hedo, P. Gorden, D. E. Brasel, T. Pokora, and R. R. Engel. 1982. Decreased insulin binding in cultured lymphocytes from two patients with extreme insulin resistance. J. Clin. Endocrinol. Metab. 54:919-930.

9. Kahn, C. R., J. S. Flier, R. S. Bar, J. A. Archer, P. Gorden, M. M. Martin, and J. Roth. 1976. The syndromes of insulin resistance and acanthosis nigricans. Insulin-receptor disorders in man. N. Engl. J. Med. 294:739-745.

10. Bar, R. S., M. Muggeo, C. R. Kahn, P. Gorden, and J. Roth. 1980. Characterization of the insulin receptors in patients with the syndromes of insulin resistance and acanthosis nigricans. Diabetologia. 18: 209-216.

11. Taylor, S. I., L. H. Underhill, J. A. Hedo, J. Roth, M. S. Rios, and R. M. Blizzard. 1983. Decreased insulin binding to cultured cells from a patient with the Rabson-Mendenhall syndrome: dichotomy between studies with cultured lymphocytes and cultured fibroblasts. J. Clin. Endocrinol. Metab. 56:856-861.

12. Taylor, S. I., J. Roth, R. M. Blizzard, and M. J. Elders. 1981. Qualitative abnormalities in insulin binding in a patient with extreme insulin resistance: decreased sensitivity to alterations in temperature and pH. Proc. Natl. Acad. Sci. USA. 78:7157-7161.

13. Taylor, S. I., J. A. Hedo, L. H. Underhill, M. Kasuga, M. J. Elders, and J. Roth. 1982. Extreme insulin resistance in association with abnormally high binding affinity of insulin receptors in a patient with leprechaunism: Evidence for a defect intrinsic to the receptor. J. Clin. Endocrinol. Metab. 55:1108-1113.

14. Taylor, S. I., and S. Leventhal. 1983. Defect in cooperativity in insulin receptors from a patient with a congenital form of extreme insulin resistance. J. Clin. Invest. 71:1676-1685.

15. McElduff, A., J. A. Hedo, S. I. Taylor, J. Roth, and P. Gorden. 1984. Insulin receptor degradation is accelerated in cultured lymphocytes 
from patients with genetic syndromes of extreme insulin resistance. $J$. Clin. Invest. 74:1366-1374.

16. Grunberger, G., Y. Zick, and P. Gorden. 1984. Defect in phosphorylation of insulin receptors in cells from an insulin-resistant patient with normal insulin binding. Science (Wash. DC). 223:932-934.

17. Grunberger, G., R. J. Comi, S. I. Taylor, and P. Gorden. 1984. Tyrosine kinase activity of the insulin receptor of patients with type A extreme insulin resistance: studies with circulating mononuclear cells and cultured lymphocytes. J. Clin. Endocrinol. Metab. 59:1152-1158.

18. Barnes, N. D., P. J. Palumbo, A. B. Hayles, and H. Folgar. 1974. Insulin resistance, skin changes, and virilization: a recessively inherited syndrome possibly due to pineal gland dysfunction. Diabetologia. 10: 285-289.

19. McNatty, K. P., D. M. Smith, A. Makris, C. DeGrazia, D. Tulchinsky, R. Oaathanondh, I. Schiff, and K. J. Ryan. 1980. The intraovarian sites of androgen and estrogen formation in women with normal and hyperandrogenic ovaries as judged by in vitro experiments. J. Clin. Endocrinol. Metab. 50:755-763.

20. Whittaker, J., Y. Zick, J. Roth, and S. I. Taylor. 1985. Insulinstimulated receptor phosphorylation appears normal in cultured EpsteinBarr virus transformed lymphocyte cell lines derived from patients with extreme insulin resistance. J. Clin. Endocrinol. Metab. 60:381-386.

21. Hedo, J. A., C. R. Kahn, M. Hayashi, K. M. Yamada, and M. Kasuga. 1983. Biosynthesis and glycosylation of the insulin receptor. Evidence for a single polypeptide precursor of the two major subunits. J. Biol. Chem. 258:10020-10026.

22. Hedo, J. A., M. Kasuga, E. Van Obberghen, J. Roth, and C. R. Kahn. 1981. Direct demonstration of glycosylation of insulin receptor subunits by biosynthetic and external labeling: evidence for heterogeneity. Proc. Natl. Acad. Sci. USA. 78:4791-4795.

23. Deutsch, P. J., C. F. Wan, O. M. Rosen, and C. S. Rubin. 1983. Latent insulin receptors and possible receptor precursors in 3T3-L1 adipocytes. Proc. Natl. Acad. Sci. USA. 80:133-136.

24. Jacobs, S. J., F. C. J. Kull, and P. Cuatrecasas. 1983. Monensin blocks the maturation of receptors for insulin and somatomedin C: iden- tification of receptor precursors. Proc. Natl. Acad. Sci. USA. 80:12281231.

25. Ullrich, A., J. R. Bell, E. Y. Chen, R. Herrera, L. M. Petruzelli, T. J. Dull, A. Gray, L. Coussens, Y.-C. Liao, M. Tsubokawa, A. Mason, P. H. Seeburg, C. Grunfeld, O. M. Rosen, and J. Ramachandran. 1985. Human insulin receptor: relationship to the tyrosine kinase family of oncogenes. Nature (Lond.). 313:756-761.

26. Wagman, L. D., S. R. Lambert, A. McElduff, P. Gorden, and J. Roth. 1983. Down-regulation occurs normally in cultured Epstein-Barr virus-transformed lymphocytes from patients with extreme insulin resistance: discrepancy between down-regulation in vivo and in vitro. $\mathrm{Di}$ abetes. 33:421-427.

27. Kasuga, M., C. R. Kahn, J. A. Hedo, E. Van Obberghen, and K. M. Yamada. 1978. Insulin-induced receptor loss in cultured human lymphocytes is due to accelerated receptor degradation. Proc. Natl. Acad. Sci. USA. 78:6917-6921.

28. Blackshear, P. J., R. A. Nemenoff, and J. Avruch. 1983. Insulin binds to and promotes the phosphorylation of a $M_{r} 210,000$ component of its receptor in detergent extracts of liver microsomes. FEBS (Fed. Eur. Biochem. Soc.) Lett. 158:243-246.

29. Olefsky, J. M. 1981. Insulin resistance and insulin action: an in vitro and in vivo perspective. Diabetes. 30:148-162.

30. Schilling, E. E., M. M. Rechler, C. Grunfeld, and A. M. Rosenberg. 1979. Primary defect of insulin receptors in skin fibroblasts cultured from an infant with leprechaunism and insulin resistance. Proc. Natl. Acad. Sci. USA. 76:5877-5881.

31. Bar, R. S., M. Muggeo, J. Roth, C. R. Kahn, J. Havrankova, and J. Imperato-McGinley. 1978. Insulin resistance, acanthosis nigricans, and normal insulin receptors in a young woman: evidence for a postreceptor defect. J. Clin. Endocrinol. Metab. 47:620-625.

32. D'Ercole, A. J., L. E. Underwood, J. Groelke, and A. Piet. 1979. Leprechaunism: studies of the relationship among hyperinsulinism, insulin resistance, and growth retardation. J. Clin. Endocrinol. Metab. 48: 495-502. 